\title{
PERBEDAAN HASIL BELAJAR SISWA MENGGUNAKAN MODEL DIRECT INSTRUCTION DITINJAU DARI GAYA BERPIKIR SISWA
}

\author{
Muhammad Safei \\ Sekolah Menengah Kejuruan Negeri 1 Kota Bima \\ safeismk1kobi@gmail.com
}

\begin{abstract}
ABSTRAK
Penelitian ini bertujuan untuk mengetahui perbedaan hasil belajar antara masingmasing kelompok gaya berpikir siswa. Pengambilan sampel menggunakan teknik multi-stage random sampling dengan data diambil dengan pendekatan one-shot model. Data tersebut kemudian dianalisis menggunakan analisis varians (ANOVA) satu jalur dan uji LSD (Least Significant Difference). Hasil analisis data adalah: (1) terdapat perbedaan yang signifikan hasil belajar siswa pada materi aplikasi barisan dan deret aritmatika menggunakan model direct instruction antara siswa gaya berpikir Sekuensial Konkret (SK), gaya berpikir Sekuensial Abstrak (SA), gaya berpikir Acak Konkret (AK), dan gaya berpikir Acak Abstrak (AA); (2) Jika membandingkan perbedaan hasil belajar antara kelompok gaya berpikir siswa tersebut, maka: (a) Siswa gaya berpikir Sekuensial Abstrak (SA) lebih tinggi dari pada siswa gaya berpikir Sekuensial Konkret (SK), Acak Konkret (AK), dan Acak Abstrak (AA), (b) Siswa gaya berpikir Sekuensial Konkret (SK) lebih tinggi dari pada siswa gaya berpikir Acak Konkret (AK) dan Acak Abstrak (AA), dan (c) Siswa gaya berpikir Acak Konkret (AK) lebih tinggi dari pada siswa gaya berpikir Acak Abstrak (AA).
\end{abstract}

Kata kunci: Gaya berpikir, model direct instruction, dan hasil belajar. 


\begin{abstract}
This study is aimed to determine the differences of the students' learning outcomes between each groupsof students' thinking styles.Take the sample of multi-stage random sampling by one-shot model approach. While student learning outcomes data obtained using achievement test instruments. The data is then analyzed using variananalysis (anova) test and one-way LSD (least Significant difference). The results of data analysis : (1) there were the significant differences on the students' learning outcomes towards the materials application sequences and arithmetic series using direct instruction model between students' Concrete Sequential thinking style (CS), Abstract Sequential thinking style (AS), Concrete Random thinking style $(C R)$, and Abstract Random thinking style (AR); (2) if it's compared the difference of learning outcomes between the groups of students' thinking style, that: (a) students' Abstract Sequential thinking style (AS) were higher than students' Concrete Sequential thinking style (CS), Concrete Random (CR), and Abstract Random (AR), (b) students' Concrete Sequential thinking style (CS) were higher than students' Concrete Random thinking style (CR) and Abstract Random (AR), and (c) students' Concrete Random thinking style (CR) were higher than students' Abstract Random thinking style (AR).
\end{abstract}

Keywords: Thinking Style, direct instruction model, and learning outcomes. 


\section{PENDAHULUAN}

Peningkatan mutu pendidikan merupakan salah satu program dari setiap Negara. Pemerintah Indonesia telah berupaya dengan berbagai macam program dan kebijakan yang mengarah kepada tercapainya tujuan pendidikan nasional, dintaranya dilakukannya pengembangan kurikulum, adanya pendidikan dan pelatihan untuk guru-guru, serta kebijakan terhadap tuntutan profesionalisme guru melalui program guru bersertifikasi.

Guru berkontribusi besar dalam mengemban tugasnya untuk mencerdaskan siswa. Profesionalisme dan pengembangan diri yang diinginkan oleh pemerintah merupakan suatu keharusan bagi guru dalam melaksanakan tugasnya. Tuntutan itu muncul karena banyaknya masalah dibidang pendidikan seperti rendahnya kualitas kompetensi yang dimiliki siswa di tiap jenjang pendidikan baik itu kemampuan kompetensi akademik secara keseluruhan maupun kemampuan kompetensi keterampilan yang dimiliki siswa Sekolah Menengah Kejuruan (SMK).

Hasil tes PISA (Program for International Student Assessment) tahun 2009, tes yang diselenggarakan OECD (Organization for Economic Cooperation and Development) diantara para pelajar umur 15 tahun dari 65 negara yang diuji kemampuannya di tiga bidang: sains, membaca, dan matematika Indonesia tetap di papan bawah: peringkat ke-60 untuk sains, peringkat ke-57 untuk membaca, dan peringkat ke-61 untuk matematika. Sedangkan Shanghai Cina ranking 1, Finlandia ranking 2, dan Korea Selatan ranking 3 (Batubara, 2013)

Kemampuan siswa memahami materi matematika masih relatif rendah, apalagi yang berhubungan dengan materi aplikasi. Siswa terbiasa menyelesaikan soal-soal dengan menggunakan algoritma rutin. Hal ini tidak sesuai dengan prinsip dan tujuan pembelajaran matematika, bahwa apa yang dipelajari harus mampu diaktualisasikan dalam kehidupan nyata. Akibatnya, nilai hasil belajar siswa pada soal aplikasi cukup bervariasi. Setelah dilakukan identifikasi terhadap hasil yang diperoleh siswa dari soal aplikasi ternyata siswa mengalami kesulitan dalam menggunakan konsep-konsep dasar matematika ke dalam soal aplikasi. Hal ini disebabkan, bahwa dalam proses pembelajaran ada kecenderungan-kecenderungan tersendiri dari siswa dalam mengolah suatu informasi. Masalah tersebut juga ditemukan pada saat proses pembelajaran materi barisan dan deret aritmatika.

Kondisi realitas yang dialami siswa tersebut, guru perlu memperhatikan sisi lain untuk mengatasinya. Sebagai manusia, siswa memiliki sifat dasar masing-masing. Oleh karena itu, 
setiap siswa memiliki gaya dan cara belajar yang sesuai dengan sifatnya. Di antara kunci utama sukses dalam belajar adalah mengetahui cara kerja otak dan mengetahui cara belajar sesuai dengan cara kerja otak (Widodo, 2010:96). Pada otak manusia ada bagian neokorteks. Bagian otak ini menurut DePorter dan Hernacki (2011:28) merupakan tempat bersemayamnya kecerdasan Anda. Adanya potensi kecerdasan tersebut, maka siswa adalah individu yang bisa dikembangkan kemampuan kompetensinya.

Membentuk tingkah laku siswa untuk mau belajar dan bisa memahami materi yang diajarkan sangat dipengaruhi oleh tingkat profesionalisme seorang guru pada waktu membawakan materi disamping faktor kemampuan inteligensi siswa. Guru dalam mengajar matematika akan mampu memberikan intervensi yang cocok bila menguasai dengan baik materi matematika yang diajarkannya, teori belajar yang cocok dengan materi, kondisi siswa, dan kondisi lingkungan sekitarnya. Agar guru dapat memilih strategi belajar mengajar dengan tepat ia harus memiliki pengetahuan khusus, seperti pengetahuan tentang inteligensi, teori belajar mengajar, hakekat bidang studi yang diajarkan, pengajaran bidang studi, pendekatanpendekatan dalam bidang studi yang diajarkan, pengajaran klasikal, dan pengajaran individual (Ruseffendi, 1988).

Proses pembelajaran bukan merupakan suatu proses transformasi pengetahuan dengan cara mentransfer dari pikiran seseorang ke pikiran orang lain tetapi harus dibangun sendiri oleh si pembelajar dalam pikirannya. Lev Vigotsky dalam Sutawidjaja dan Afgani (2011:1.10) mengatakan bahwa seseorang memperoleh pengetahuan dengan cara mengkonstruksi (membangun) pengetahuan tersebut di dalam pikirannya. Demikian juga pendapat Piaget dalam Sutawidjaja dan Afgani (2011:1.10) yang mengatakan bahwa pengetahuan dan informasi tidak diterima secara pasif oleh pembelajar, tetapi konstruksi oleh pembelajar di dalam pikirannya.

Kenyataannya, siswa dalam mengkonstruksi materi pelajaran dalam pikirannya masih mangalami kesulitan, apalagi yang berhubungan dengan materi aplikasi pada pembelajaran matematika. Untuk itu perlu adanya peran guru untuk memilih model pembelajaran yang tepat dalam membantu mengkonstruksi pola pikir siswa. Model pembelajaran yang memberikan kesempatan kepada guru untuk mengkonstruksi pola pikir siswa dalam belajar matematika adalah model direct instruction. Model ini bukan berarti siswa pasif dalam mengkonstruksi 
pembelajaran dalam pikirannya tetapi akan memberikan stimulus terhadap siswa untuk termotivasi melakukan konstruksi lebih lanjut terhadap materi yang dipelajarinya.

Sebagai salah satu model yang digunakan dalam pembelajaran matematika, model direct instruction sudah memberikan kontribusi yang positif terhadap peningkatan hasil belajar siswa. Sutawidjaja dan Afgani (2011:2.9) menyatakan bahwa:

Hasil-hasil penelitian secara konsisten menunjukkan bahwa tidak ada kesimpulan yang absolud bahwa pembelajaran yang berpusat pada siswa jauh lebih baik dibandingkan dengan pembelajaran yang berpusat pada guru dalam hal ini model direct instruction. Hasil penelitian lain juga secara konsisten menunjukkan bahwa kemampuan guru dalam memberikan informasi yang jelas dan spesifik kepada siswa memberikan dampak yang positif terhadap proses belajar siswa.

Guru dalam mengkonstruksi pola pikir siswa akan berjalan dengan maksimal apabila mengetahui cara kerja otak. Otak kanan dan otak kiri adalah dua bagian otak yang mempunyai peranan tersendiri. Masing-masing dari dua belahan otak tersebut bertanggung jawab atas cara berpikir yang berbeda-beda dan mengkhususkan dari pada kemampuan-kemampuan tertentu, walaupun penyilangan memang terjadi (DePorter dan Harnacky, 2011:39). Meskipun kedua otak tersebut masing-masing punya peranan tersendiri, dalam beraktivitas sangat dibutuhkan peranan kedua belahan otak tersebut dalam waktu yang sama. Agar fungsi kedua belahan otak tersebut seimbang dan berfungsi dalam waktu yang sama, maka peran otak tengahlah sebagai jembatan penghubung antara kedua belahan otak tersebut. Fungsi dari otak tengah adalah sebagai jembatan antara otak kiri dan otak kanan (Soepiadhy 2011:22).

Sistem pendidikan kita kurang memperhatikan karakteristik dari masing-masing fungsi otak kanan dan otak kiri, karena menurut Khoo (2008:43) mata pelajaran yang diajarkan disekolah adalah $90 \%$ mata pelajaran berbasis otak kiri. Proses pembelajaran matematikapun masih didominasi oleh sistem pembelajaran yang berpihak kepada otak kiri. Hal ini bertentangan dengan hakekat matematika, bahwa matematika bukan sekedar berhitung secara mekanis dan prosedural (menggunakan otak kiri), melainkan juga bernalar dan berpikir secara kreatif dan inovatif (Masykur dan Fathani, 2007:152). Kreatifitas yang ada pada otak kanan sangat berkontribusi terhadap proses berpikir dari otak kiri. Menurut Masykur dan Fathani (2007:154) bahwa untuk merangsang serta mengoptimalkan kecerdasan logis matematika tersebut, kita harus mengkodisikan otak anak untuk siap menerima materi dengan situasi dan 
cara pembelajaran yang menyenangkan, yakni prinsip belajar dengan menggunakan peran otak kanan, seperti belajar sambil bermain dan bermain sambil belajar.

Adanya kecenderungan tersendiri dari peran dan cara berpikir dari otak kanan dan otak kiri tersebut DePorter dan Hernacky (2011:124) menyatakan bahwa orang yang dominan otak kanan kecenderungan gaya berpikirnya bersifat Acak Abstrak (AA) dan Acak Konkret (AK). Sedangkan orang yang dominan otak kiri kecenderungan gaya berpikirnya bersifat Sekuensial Abstrak (SA) dan Sekuensial Konkret (SK).

Gaya berpikir SK berpegang pada kenyataan dan memproses informasi dengan cara yang teratur, linier, dan sekuensial (DePorter dan Hernacki, 2011: 128) . Gaya berpikir SA lebih kepada berpikir dalam konsep dan menganalisis informasi (DePorter dan Hernacki, 2011: 134). Gaya berpikir AK berpegang pada realitas dan mempunyai sikap ingin mencoba (DePorter dan Hernacki, 2011: 131). Sedangkan gaya berpikir AA akan mengatur informasi melalui refleksi dan berkiprah di dalam lingkungan tidak teratur yang beroriontasi pada orang (DePorter dan Harnacky, 2011:133).

Menurut Stemberg (1971) dalam Santrock (2004) yang dikutip Wawank (2011) bahwa gaya berpikir dan belajar merupakan cara yang dipilih seseorang untuk menggunakan kemampuannya. Kemampuan siswa menggunakan gaya berpikir dalam belajar akan memberikan pengaruh yang berbeda terhadap hasil belajar. Hal ini sesuai dengan hasil penelitian Sarana (2011) bahwa gaya berpikir siswa baik SK, SA, AK, dan AA memiliki pengaruh yang berbeda terhadap hasil belajar matematika serta siswa yang mempunyai gaya berpikir sekuensial (SK dan SA) lebih baik dibanding gaya berpikir acak (AK dan AA) ditinjau dari hasil belajar matematika. Sedangkan menurut Darajat (2004), bahwa hasil belajar siswa yang mempunyai gaya berpikir SA lebih baik dari pada siswa yang mempunyai gaya berpikir SK.

Berdasarkan teori-teori, hasil-hasil penelitian, dan pandangan umum tentang kecenderungan dari masing-masing gaya berpikir tersebut, maka di rasakan perlu untuk melakukan penelitian tentang hasil belajar siswa bila ditinjau dari gaya berpikir tersebut. Penelitian ini bertujuan untuk mengetahui perbedaan hasil belajar siswa pada materi aplikasi barisan dan deret aritmatika menggunakan model direct instruction antara siswa gaya berpikir SK, SA, AK, dan AA. 


\section{METODE PENELITIAN}

Penelitian ini merupakan penelitian eksperimen semu (quasi experiment). Pengambilan datanya menggunakan pendekatan one-shot model, yaitu pendekatan yang menggunakan satu kali pengumpulan data pada suatu saat (Arikunto, 2010:122).

Populasi dalam penelitian ini adalah siswa kelas XI Bidang Studi Keahlian Bisnis dan Manajemen SMKN 1 Kota Bima yang terdiri dari Program Studi Keahlian Keuangan dan Program Studi Keahlian Tata Niaga. Pengambilan sampel menggunakan teknik multi-stage random sampling, yaitu metode pengambilan sampel dengan cara populasi dibagi ke dalam kelompok-kelompok yang homogen. Sampel diambil secara random dengan cara undian antara masing-masing Program Studi Keahlian. Adapun sampel dalam penelitian ini dapat dilihat pada tabel berikut:

Tabel 1. Sampel Penelitian

\begin{tabular}{lccc}
\hline No & Program Studi Keahlian & Kelas & Jumlah Siswa \\
\hline \multirow{2}{*}{1} & Keuangan & XI Keuangan 2 & 27 \\
\cline { 3 - 4 } & & XI Keuangan 3 & 27 \\
\hline 2 & Tata Niaga & Tata Niaga & 30 \\
\hline & Jumlah & 84 \\
\hline
\end{tabular}

Untuk mendapatkan data gaya berpikir dari 84 siswa tersebut, dilakukan tes gaya berpikir dengan menggunakan instrumen tes dari John Park Le Tellier (DePorter dan Hernacki, 2011:125). Hasil dari tes tersebut diperoleh 25 siswa kelompok gaya berpikir SK, 17 siswa kelompok gaya berpikir SA, 22 siswa kelompok gaya berpikir AK, dan 20 siswa kelompok gaya berpikir AA.

Kelompok-kelompok siswa berdasarkan gaya berpikir tersebut sebelum dilakukan pengambilan data hasil belajar, dalam proses pembelajarannya diperlakukan sama dengan menggunakan model direct instruction. Data yang diperoleh akan dianalisis menggunakan statistik parametris, yaitu uji analisis varians (ANOVA) satu jalur dan uji LSD (Least Significant Difference) menggunakan program SPSS for windows versi 16 pada taraf signifikansi 0,05. Batas keputusan uji analisis varians (ANOVA) satu jalur dan uji LSD (Least Significant Difference) dapat dilihat dari nilai sig. nya. Jika nilai sig. nya lebih kecil daripada 
Alpha (0,05) yang kita tetapkan, maka hipotesis nol di tolak (Sugilar dan Juandi, 2011:5.14).

Uji (ANOVA) satu jalur dilakukan untuk mengetahui secara umum perbedaan hasil belajar siswa pada materi aplikasi barisan dan deret aritmatika menggunakan model direct instruction antara siswa gaya berpikir SK, SA, AK, dan AA. Apabila dari hasil uji tersebut terdapat perbedaan, maka dilanjutkan dengan uji LSD (Least Significant Difference) untuk mengetahui perbedaan hasil belajar antara masing-masing dua kelompok gaya berpikir siswa.

\section{HASIL DAN PEMBAHASAN}

Adapun data hasil penelitian dapat dilihat pada tabel deskripsi statistik data penelitian berikut:

Tabel 2. Deskripsi Statistik Data Penelitian

\begin{tabular}{ccccccc}
\hline Gaya berpikir & N & $\begin{array}{c}\text { Mini- } \\
\text { mum }\end{array}$ & $\begin{array}{c}\text { Maksi- } \\
\text { mum }\end{array}$ & Jumlah & $\begin{array}{c}\text { Rata- } \\
\text { rata }\end{array}$ & $\begin{array}{c}\text { Standar } \\
\text { deviasi }\end{array}$ \\
\hline $\begin{array}{c}\text { Sekuensial } \\
\text { Konkret }\end{array}$ & 25 & 50 & 80 & 1573 & 62,92 & 9,464 \\
\hline Sekuensial Abstrak & 17 & 48 & 83 & 1188 & 69,88 & 9,701 \\
\hline Acak Konkret & 22 & 44 & 69 & 1238 & 56,27 & 7,465 \\
\hline Acak Abstrak & 20 & 34 & 65 & 1003 & 50,15 & 10,001 \\
\hline
\end{tabular}

Setelah memenuhi syarat uji normalitas dan homogenitas data, maka hasil uji analisis varians (ANOVA) satu jalur dapat dilihat pada tabel berikut:

Tabel 3. Hasil Uji Analisis Varians (ANOVA) Satu Jalur

\begin{tabular}{cccccc}
\hline Sumber variasi & $\begin{array}{c}\text { Jumlah } \\
\text { kuadrat }\end{array}$ & dk & $\begin{array}{c}\text { Rata-rata } \\
\text { kuadrat }\end{array}$ & F & Sig. \\
\hline Antara kelompok & 4102.291 & 3 & 1367.430 & 16.263 & .000 \\
\hline Dalam kelompok & 6726.518 & 80 & 84.081 & & \\
& & & & & \\
\hline Total & 10828.810 & 83 & & &
\end{tabular}


Hasil uji tersebut menunjukkan nilai sig. $0,000<0,05$. Artinya terdapat perbedaan hasil belajar siswa pada materi aplikasi barisan dan deret aritmatika menggunakan model direct instruction antara siswa gaya berpikir SK, SA, AK, dan AA.

Adapun hasil uji LSD (Least Significant Difference) dapat dilihat pada tabel berikut:

Tabel 4. Hasil Uji LSD (Least Significant Difference)

\begin{tabular}{ccccc}
\hline $\begin{array}{c}\text { Uji Perbedaan hasil belajar } \\
\text { siswa antar dua kelompok } \\
\text { gaya berpikir }\end{array}$ & $\begin{array}{c}\text { Selisih } \\
\text { rata- } \\
\text { rata }\end{array}$ & $\begin{array}{c}\text { Sig. } \\
\text { kepercayaan } \\
(\mathbf{9 5 \% )}\end{array}$ \\
\cline { 4 - 6 } & & & $\begin{array}{c}\text { Interval } \\
\text { batas }\end{array}$ & $\begin{array}{c}\text { Batas } \\
\text { atas }\end{array}$ \\
\hline SK dengan SA & 6.962 & .018 & 1.23 & 12.70 \\
\hline SK dengan AK & 6.647 & .015 & 1.31 & 11.98 \\
\hline SK dengan AA & 12.770 & .000 & 7.30 & 18.24 \\
\hline SA dengan AK & 13.610 & .000 & 7.72 & 19.50 \\
\hline SA dengan AA & 19.732 & .000 & 13.71 & 25.75 \\
\hline AK dengan AA & 6.123 & .034 & .48 & 11.76 \\
\hline
\end{tabular}

Hasil uji tersebut menunjukkan semua nilai sig. nya $<0,05$. Artinya terdapat perbedaan hasil belajar siswa antara masing-masing dua kelompok gaya berpikir siswa tersebut.

Berdasarkan hasil pengujian hipotesis melalui uji analisis varians (ANOVA) satu jalur dan dilanjutkan dengan uji LSD (Least Significant Difference) ternyata kemampuan siswa dalam menyelesaikan soal aplikasi barisan dan deret aritmatika menggunakan model direct instruction terdapat perbedaan hasil yang signifikan jika ditinjau dari gaya berpikir siswa. Demikian juga hasil penelitian Sarana (2011), bahwa gaya berpikir siswa baik SK, SA, AK, dan AA memiliki pengaruh yang berbeda terhadap hasil belajar matematika.

Perbedaan hasil belajar tersebut diketahui pula bahwa kelompok siswa gaya berpikir SA lebih tinggi nilai rata-ratanya jika dibandingkan dengan nilai rata-rata kelompok siswa gaya berpikir SK. Hal ini sesuai dengan hasil penelitian Darajat (2004), bahwa hasil belajar siswa yang mempunyai gaya berpikir SA lebih baik dari pada siswa yang mempunyai gaya berpikir SK. 
Kelompok siswa gaya berpikir SK lebih tinggi nilai rata-ratanya jika dibandingkan dengan nilai rata-rata kelompok siswa gaya berpikir AK dan AA. Kelompok siswa gaya berpikir SA lebih tinggi nilai rata-ratanya jika dibandingkan dengan nilai rata-rata kelompok siswa gaya berpikir AK dan AA. Hal ini sesuai dengan hasil penelitian Sarana (2011), bahwa siswa yang mempunyai gaya berpikir sekuensial (SK dan SA) lebih baik dibanding gaya berpikir acak (AK dan AA) ditinjau dari hasil belajar matematika. Sedangkan kelompok siswa gaya berpikir AK lebih tinggi nilai rata-ratanya jika dibandingkan dengan nilai rata-rata kelompok siswa gaya berpikir AA. Hal ini sesuai dengan hasil penelitian Sarana (2011), bahwa gaya berpikir siswa baik SK, SA, AK, dan AA memiliki pengaruh yang berbeda terhadap hasil belajar matematika.

Menurut DePorter dan Hernacki (2011: 134) bahwa diantara kecenderungan cara berpikir kelompok siswa gaya berpikir SA lebih rasional dan logis sedangkan kelompok siswa gaya berpikir SK di antara kecenderungan cara berpikirnya menyukai pengarahan dan prosedur khusus. Artinya jika pengarahan dan prosedur khusus belum dipahami, maka kelompok siswa gaya berpikir SK akan mengalami kesulitan dalam memahami materi pelajaran. Inilah yang menjadi kelemahan kelompok gaya berpikir SK, sehingga menyebabkan hasil belajarnya rendah jika dibandingkan dengan kelompok siswa gaya berpikir SA pada materi aplikasi barisan dan deret aritmatika.

Kelompok siswa gaya berpikir SK mudah mengingat fakta-fakta, rumus-rumus, dan aturan-aturan serta menyukai pengarahan dan prosedur khusus (DePorter dan Hernacki, 2011: 128). Sedangkan kelompok siswa gaya berpikir AK mempunyai sikap ekperimental yang diiringi dengan perilaku yang tidak terstruktur (DePorter dan Harnacky, 2011: 130). Perilaku yang tidak terstruktur ini di sebabkan cara berpikinya yang tidak terstruktur. Sedangkan matematika merupakan ilmu yang sangat terstruktur. Hal inilah yang menjadi dasar bahwa kelompok siswa gaya berpikir AK kurang berprestasi dalam belajar matematika. Akibatnya hasil belajar kelompok siswa gaya berpikir SK lebih baik dari pada kelompok siswa gaya berpikir AK pada materi aplikasi barisan dan deret aritmatika.

Kelompok siswa gaya berpikir SK mudah mengingat fakta-fakta, rumus-rumus, dan aturan-aturan serta menyukai pengarahan dan prosedur khusus (DePorter dan Hernacki, 2011: 128). Sedangkan kelompok siswa gaya berpikir AA mempunyai sifat tidak suka berada pada lingkungan yang serba diatur dan akan bekerja lebih baik pada situasi yang kreatif (DePorter 
dan Harnacky, 2011: 132). Mengingat model direct instruction kurang memberikan kesempatan kepada siswa untuk berkreatif dan diterapkan pada proses kegiatan belajar mengajar di kelas, maka siswa gaya berpikir AA kurang berkembang dalam memahami materi pelajaran. Sehingga hasil belajar kelompok siswa gaya berpikir SK lebih baik dari pada hasil belajar kelompok siswa gaya berpikir AA pada materi aplikasi barisan dan deret aritmatika.

Cara berpikir kelompok siswa gaya berpikir SA diantaranya adalah berpikir secara rasional dan logis (DePorter dan Hernacki, 2011: 134). Kemampuan berpikir yang mendasar tersebut membuat siswa kelompok gaya berpikir SA lebih mudah memahami matematika. Sedangkan kelompok siswa gaya berpikir AK mempunyai sifat dan perilaku yang tidak terstruktur (DePorter dan Harnacky, 2011: 130). Mengingat perilaku yang tidak terstruktur dipengaruhi oleh cara berpikir yang tidak terstruktur, maka kelompok siswa gaya berpikir AK tidak mampu memahami pelajaran matematika dengan baik. Oleh sebab itu, siswa kelompok gaya berpikir SA lebih baik hasil belajarnya jika dibandingkan dengan kelompok siswa gaya berpikir AK pada materi aplikasi barisan dan deret aritmatika.

Cara berpikir kelompok siswa gaya berpikir SA diantaranya adalah berpikir secara rasional dan logis (DePorter dan Hernacki, 2011: 134). Kemampuan berpikir yang mendasar tersebut membuat siswa kelompok gaya berpikir SA lebih mudah memahami matematika. Sedangkan kelompok siswa gaya berpikir AA mempunyai sifat tidak suka berada pada lingkungan yang serba diatur dan akan bekerja lebih baik pada situasi yang kreatif (DePorter dan Harnacky, 2011: 132). Mengingat model direct instruction kurang memberikan kesempatan kepada siswa untuk berkreatif dan diterapkan pada proses kegiatan belajar mengajar di kelas, maka siswa gaya berpikir AA kurang berkembang dalam memahami materi pelajaran. Sehingga hasil belajar kelompok siswa gaya berpikir SA lebih baik dari pada hasil belajar kelompok siswa gaya berpikir AA pada materi aplikasi barisan dan deret aritmatika.

Siswa gaya berpikir AK mempunyai dorongan yang kuat untuk menemukan alternatif dan mengerjakan dengan cara sendiri, serta melakukan pendekatan trial and error (DePorter dan Harnacky, 2011: 130). Adanya dorongan yang kuat untuk menemukan alternatif dan selalu ingin mencoba akan memberikan sebuah harapan bahwa kelompok siswa gaya berpikir AK masih mempunyai semangat untuk belajar. Siswa yang gaya berpikir AA tidak suka berada pada lingkungan yang serba diatur, akan bekerja dengan baik dalam situasi tertentu, serta perasaan dan emosi akan mempengaruhi suasana belajar (DePorter dan Harnacky, 2011: 
132). Karakter siswa yang dimiliki oleh kelompok gaya berpikir AA tersebut memberikan gambaran bahwa dalam belajar sangat tergantung dari situasi dan kondisi lingkungan belajar. Hal inilah yang menjadi kendala bagi siswa tersebut kurang berhasil dalam belajar. Sehingga hasil belajar kelompok siswa gaya berpikir AK lebih baik dari pada hasil belajar kelompok siswa gaya berpikir AA pada materi aplikasi barisan dan deret aritmatika.

\section{KESIMPULAN}

Berdasarkan hasil penelitian dan pembahasan, maka simpulan yang dapat diambil dari penelitian ini adalah:

1. Terdapat perbedaan yang signifikan hasil belajar siswa pada materi aplikasi barisan dan deret aritmatika menggunakan model direct instruction antara siswa gaya berpikir Sekuensial Konkret (SK), gaya berpikir Sekuensial Abstrak (SA), gaya berpikir Acak Konkret (AK), dan gaya berpikir Acak Abstrak (AA). Perbedaan tersebut menunjukkan bahwa:

a. Hasil belajar siswa gaya berpikir Sekuensial Konkret (SK) berbeda dengan siswa gaya berpikir Sekuensial Abstrak (SA).

b. Hasil belajar siswa gaya berpikir Sekuensial Konkret (SK) berbeda dengan siswa gaya berpikir Acak Konkret (AK).

c. Hasil belajar siswa gaya berpikir Sekuensial Konkret (SK) berbeda dengan siswa gaya berpikir Acak Abstrak (AA).

d. Hasil belajar siswa gaya berpikir Sekuensial Abstrak (SA) berbeda dengan siswa gaya berpikir Acak Konkret (AK).

e. Hasil belajar siswa gaya berpikir Sekuensial Abstrak (SA) berbeda dengan siswa gaya berpikir Acak Abstrak (AA).

f. Hasil belajar siswa gaya berpikir Acak Konkret (AK) berbeda dengan siswa gaya berpikir Acak Abstrak (AA).

2. Jika membandingkan perbedaan hasil belajar antara kelompok gaya berpikir siswa tersebut, maka:

a. Siswa gaya berpikir Sekuensial Abstrak (SA) lebih tinggi dari pada siswa gaya berpikir Sekuensial Konkret (SK), Acak Konkret (AK), dan Acak Abstrak (AA). 
b. Siswa gaya berpikir Sekuensial Konkret (SK) lebih tinggi dari pada siswa gaya berpikir Acak Konkret (AK) dan Acak Abstrak (AA).

c. Siswa gaya berpikir Acak Konkret (AK) lebih tinggi dari pada siswa gaya berpikir Acak Abstrak (AA).

\section{REKOMENDASI}

Berdasarkan simpulan dari hasil penelitian dan pembahasan tersebut, maka perlu disampaikan rekomendasi sebagai berikut:

1. Bagi pengemban instruktur matematika:

a. Perlu dilakukan penelitian untuk dapat membedakan hasil belajar siswa pada materi aplikasi barisan dan deret aritmatika menggunakan model pembelajaran yang lain ditinjau dari gaya berpikir siswa.

b. Perlu dilakukan penelitian lanjutan untuk dapat membedakan hasil belajar siswa pada materi yang lain dengan menggunakan model direct instruction ditinjau dari gaya berpikir siswa.

c. Perlu dilakukan penelitian untuk menentukan model pembelajaran yang sesuai dengan masing-masing kelompok gaya berpikir siswa.

2. Bagi sekolah, pembagian rombongan belajar sebaiknya memperhatikan gaya berpikir siswa. Hal ini dilakukan untuk memudahkan guru dalam memberikan pelayanan terhadap siswa, seperti memilih model pembelajaran yang sesuai dengan gaya berpikir siswa.

\section{UCAPAN TERIMAKASIH}

Saya menyadari bahwa, tanpa bantuan dari semua pihak, sangatlah sulit untuk menyelesaikan artikel ini, karena dalam proses penelitian dan penulisan artikel ini terdapat kendala yang dihadapi oleh penulis serta ditemukan pula kelemahan-kelemahan yang dimiliki oleh penulis. Oleh karena itu saya sampaikan terima kasih kepada:

1. Dr. Syachruddin AR., Drs. MS dan Dr. H. Agus Santoso, M.Si selaku pembimbing yang telah menyediakan waktu, tenaga, dan pikiran untuk mengarahkan saya dalam penyusunan artikel ini.

2. Muhtar, S.Pd, M.Si, selaku Kepala SMKN 1 Kota Bima yang telah memberikan ijin untuk melakukan penelitian di sekolah tersebut. 
3. Teman-teman guru SMKN 1 Kota Bima yang telah membantu terlaksananya penelitian ini.

4. Semua pihak yang telah membantu terselesaikannya penulisan tesis ini baik secara langsung maupun tidak langsung.

Akhirnya, mudah-mudahan Allah SWT memberikan safaat dan membalas segala kebaikan dari Bapak/Ibu serta semoga artikel ini dapat bermanfaat bagi pengembangan ilmu.

\section{REFERENSI}

Arikunto S. (2010). Prosedur Penelitian. Jakarta: Rineka Cipta

Darajat (2004). Pengaruh Metode Pembelajaran dan Gaya berpikir Terhadap Hasil Belajar Matematika (suatu eksperimen pada SLTP Negeri di Kota Tebing tinggi). Tesis. Diambil 20 Oktober 2012, dari situs World Wide Web http://www.digilib.unimed.ac.id/public/UNIMED-Master-163-025020136-abstrak.PDF

DePorter B. dan Hernacki M. (2011). Quantum Learning. Diterjemahkan oleh Alwiyah Abdurrahman. Bandung: Kaifah

Khoo A. (2008). Buku Pintar Anak Jenius. Jakarta: PT Mitra Media

Masykur Ag M. dan Fathani A. H. (2007). Mathematical Intelligence. Cara Cerdas Melatih Otak Dan Menanggulangi Kesulitan Belajar: Ar-Ruzz Media.

Ruseffendi, E. T. (1988). Pengantar Kepada Membantu Guru Mengembangkan Kompetensinya Dalam Pengajaran Matematika Untuk Meningkatkan CBSA. Bandung: Tarsito.

Sarana (2011). Efektifitas Pembelajaran Matematika Kooperative Jigsaw Dengan Pendekatan Matematisasi Berjenjang Ditinjau Dari Gaya Berpikir Siswa Kelas X SMA di Kabupaten Boyolali. Tesis. Diambil 3 Oktober 2012, dari situs World Wide Web http://www. pasca.uns.id/?p=2275

Soepiadhy S. (2011). Rahasia Anak Jenius. Surabaya: PT. Java Pustaka

Sugilar dan Juandi D. (2011). Metode Penelitian Pendidikan Matematika. Jakarta: Universitas Terbuka.

Sutawidjaja A. dan Afgani D. J. (2011). Pembelajaran Matematika. Jakarta: Universitas Terbuka.

Wawank (2011). Gaya Berpikir Dan Belajar. Diambil 13 Juli 2012, dari situs World Wide Web http://www.wawank-wawank.blogspot.com/2011/11/ gaya-berpikir-dan-belajar.html 
Widodo S. (2010). Smart Learning Tecnology. Jakarta: PT Elex Media Komputindo. 